ISSN 0258-7122

Bangladesh J. Agril. Res. 36(1) : 111-122, March 2011

\title{
PROFITABILITY OF SOME BARI RELEASED CROP VARIETIES IN SOME LOCATIONS OF BANGLADESH
}

\author{
MST. ESMAT ARA BEGUM ${ }^{1}$, MD. NOZRUL ISLAM ${ }^{2}$ \\ Q. M. ALAM ${ }^{3}$ AND S. M. BYAZID HOSSAIN ${ }^{4}$
}

\begin{abstract}
An attempt was made to asses the costs and returns from the cultivation of selected crops in different locations. Fifty farmers were selected for collecting data for each crop through random sampling for the year 2006-07. Study revealed that per hectare total costs were Tk. 51341, Tk. 32275, Tk. 20983, Tk. 27819, Tk. 63012, Tk. 61928, Tk. 87828, Tk. 65163, and Tk. 57775 for the cultivation of maize, groundnut, mungbean, sweet potato, cabbage, cauliflower, tomato, cucumber, and okra, respectively. Sample farmers received Tk. 31280, Tk. 23221, Tk. 12957, Tk. 70981, Tk. 56546, Tk. 72820, Tk. 247076, Tk. 61437 and Tk. 94822 per hectare as net returns from the cultivation of maize, groundnut, mungbean, sweet potato, cabbage, cauliflower, tomato, cucumber, and okra, respectively. The benefit cost ratios over total costs were 1.61, 1.72, 1.62, 3.55, 1.90, 2.17, 3.72, 1.94, and 2.64 for the cultivation of maize, groundnut, mungbean, sweet potato, cabbage, cauliflower, tomato, cucumber, and okra, respectively. High costs of fertilizers and insecticides were the major constraints to higher production for most of the crops as mentioned by the sample farmers.
\end{abstract}

Keywords: Profitability, crops, locations.

\section{Introduction}

Bangladesh has made substantial progress towards achieving its goal of foodgrain self-sufficiency. This achievement has been based on a substantial intensification of agriculture: modem rice varieties now account for almost half of the rice area; an increasing proportion of land is double- or triple- cropped; and use of chemical fertilizers has become double since the early 1980s. Continued and accelerated agricultural growth will require intensification to continue. But this intensification created problem for productivity. Because farmers do no follow the crop rotations which damage soil fertility. Therefore, minor crops should be produced if they are profitable. The present study takes an attempt to investigate this issue considering nine crops: maize, groundnut, mungbean, sweet potato, cabbage, cauliflower, tomato, cucumber, and okra.

\footnotetext{
${ }^{1}$ Scientific Officer, Agricultural Economics, Division Bangladesh Agricultural Research Institute (BARI), Gazipur. ${ }^{2}$ Principal Scientific Officer, Agricultural Economics Division, BARI, Gazipur 1701, ${ }^{3}$ Chief Scientific Officer \& Head, Agricultural Economics Division, BARI, Gazipur 1701, ${ }^{4}$ Curator, Training \& Communication Wing, BARI, Gazipur 1701, Bangladesh.
} 
Maize is one of the oldest crops in the world. It is the highest yielding grain crop having multiple uses. At present, maize is gaining popularity to the farmers due to its high productivity potential and demand for poultry feed in Bangladesh. It is evident that the area and production of maize increased about $48 \%$ and $49 \%$, respectively, in the year 2007-2008 from the previous year ( BBS, 2008 ).

Groundnut is cultivated mostly in marginal lands during both in summer and winter seasons in Bangladesh. Its area and production have steadily dropped over the past decade. Area and production of groundnut increased about $17 \%$ and 29\%, respectively, in 2007-2008 compared to the year 2002- 2003. Again, groundnut occupies only about $10 \%$ of the total area under all oil crops and contributes about 7\% to the total oil seed production in 2007- 2008 (BBS, 2008). Apart from the fact that the groundnut is an excellent oil crop, it is a good source of protein, nutritious fodder for the cattle, and profitable cash crop to the farmers.

The mungbean is a leguminous species or pulse crop grown principally for its protein-rich edible seeds. Pulses are important world food crops because they provide an inexpensive source of vegetable dietary protein. In densely populated areas like Bangladesh, the economy does not support large-scale production and utilization of animal protein. Therefore, the protein in people's diets may be augmented by supplementation with the rich pulse grains in Bangladesh. The area under mungbean in Bangladesh was 60000 acres with the production of $21000 \mathrm{M}$. tons which was about $10 \%$ of total pulse area and production during the year 2007-2008 (BBS, 2008). Area and production of mungbean decreased about $45 \%$ and $30 \%$, respectively, in 2007- 2008 compared to the year 20022003.

Sweet potatoes are mainly utilized as human foodstaff. In the tropics, the major portion of the crop is eaten straight from the ground as a vegetable, after boiling, baking or frying. The area and production under sweet potato was 78000 acres and $307000 \mathrm{M}$. tons in Bangladesh during the year 2007-2008 (BBS, 2008). Area and production of sweet potato decreased about $14 \%$ and $8 \%$, respectively in 2007- 2008 compared to that in the year 2002- 2003.

Cabbage is one of the most economically important member of genus Brassica. It is the most popular vegetable around the world in respect of area, production, and availability almost round the year (Swiader et al., 1992). The production in Bangladesh under cabbage increased 79\% in 2007-2008 compared to 2002-2003 (BBS, 2008). It covers about 3\% production under vegetable crops in 2007-2008 (BBS, 2008). Besides its nutritive value, it is a profitable cash crop for the farmers in Bangladesh.

Cauliflower is one of the most important favourite vegetable crop grown throughout the country and relished by most of the people. In comparison to other vegetables, its cultivation needs more and regular care to get better quality 
of curds. Out of a total of 159994 ha of land under winter vegetables, cauliflower occupiels $8 \%$ area. The production $(156000 \mathrm{M}$. ton) of cauliflower increased $86 \%$ in 2007- 2008 compared to $2002-2003$. It covers $2 \%$ production in the total vegetable production in 2007-2008 (BBS, 2008).

Tomato is one of the most popular vegetables grown all over the country. The production of tomato in our country was about $143000 \mathrm{M}$. tons in 2007-2008 (BBS, 2008). It increased $40 \%$ of tomato production in 2007-2008 compared to 2002-2003. It is a very good source of income to small and marginal farmers and contributes to the nutrition of the consumer.

Cucumber is one of the oldest vegetable crops grown widely throughout the country, tropical and sub-tropical parts of the world (Singh et al., 2004). Fruits are eaten raw with salt and pepper at the immature and mature stages. Mostly, the small fruits are used for pickling and big fruits are used for salads and for cooking curries. It is a good source of vitamin B and C. The production of cucumber in the country was about $37000 \mathrm{M}$. tons in 2007- 2008 (BBS, 2008).

Okra is an important vegetable crop of rainy as well as summer seasons. Its pods are mainly used for vegetables in curries. Fruits have $2 \%$ protein and are also a good source of minerals like calcium and magnesium. They also contain potash and iodine. The production of okra was $39000 \mathrm{M}$. tons during the year 2007-2008 having about 4\% share in the total summer vegetable production (BBS, 2008).

Profitability of a crop depends on yield, price of the product, and cost of inputs as well. Any variation in any of the above factors obviously will change the profitability. It is changed over time, place and management level. In the past, several studies have been undertaken on different crops and reported in different years. Only two times, consolidated reports on profitability of major crops were published by BARI in Bangladesh. At present, very little information is available on economic profitability of different crops in Bangladesh. Due to lack of information on these, the policy makers also can not adopt appropriate policy regarding its extension and development. Therefore, it is realized that there is demand from policy makers, extension agents, and researchers to provide information on profitability of some BARI released crop varieties in Bangladesh.

\section{Objectives}

The objectives of this study were:

1. to assess the costs and returns of selected BARI released crop varieties measuring the level of input used by the sample farmers; and

2. to identify the constraints to producing those crops. 


\section{Methodology}

Nine crops, such as maize, groundnut, mungbean, sweet potato, cabbage, cauliflower, tomato, cucumber, and okra were selected for this study. The study was conducted in Hatibanda Upazila of Lalmonirhat district for maize, Homna and Titas Upazila of Comilla district for groundnut, Kamalnagar Upazila of lakshmipur district for mungbean and sweet potato, Sadar Upazila of Jessore district for cabbage and cauliflower, Chandina Upazila of Comilla district for tomato, Sadar Upazila of Bogia district for cucumber and Shatkania Upazila of Chittagong district for okra. The districts and the Upazilas were selected purposively due to the high production regions of selected crops. From the population, 50 farmers were selected randomly for each crop for the year 200607. Data for the present study were collected through pre-designed and pre-tested interview schedules. Data were collected between February and April 2007. After necessary adjustments, collected data were analyzed to achieve the stipulated objectives of the study. Calculation of costs and returns were done based on the prevailing market price of each inputs and outputs for all crops in each location. Tabular methods of analysis using averages, percentages, ratios etc. were done for the study.

\section{Results and Discussion}

Maize is one of the most important crops in terms of making flour for human consumption and as well in terms of poultry feed. Groundnut is an excellent oil crop, it is a good source of protein, nutritious and fodder for the cattle, and profitable cash crop to the farmers. Pulses are also important food crops because they provide an inexpensive source of protein.

Maize is a profitable cash crop for the farmers. From the present study, it was observed that the total cost of maize production was Tk. 51341/ha of which variable cost was Tk. 33141/ha and fixed cost was Tk. 18200/ha (Table 1). Total return was Tk. 82621/ha including value of grains and by product. Study revealed that the sample farmers received Tk. 49480/ha as gross margin and Tk. 31280/ha as net returns for the production of maize. Benefit cost ratios were 2.49 and 1.61 over variable and total costs, respectively (Table 1 ). On the average, human labour used was 185 man-days/ha, seed $20 \mathrm{~kg} / \mathrm{ha}$, urea $348 \mathrm{~kg} / \mathrm{ha}$, TSP $200 \mathrm{~kg} / \mathrm{ha}$, MP $171 \mathrm{~kg} / \mathrm{ha}$, gypsum $82 \mathrm{~kg} / \mathrm{ha}$, and zinc $9 \mathrm{~kg} / \mathrm{ha}$ for the production of maize by the sample farmers. Most of the inputs, such as urea, TSP, MP, gypsum, and zinc were used lower doses by the sample farmers compared to recommended doses (Table 3).

It was found from the study that total costs of groundnut production by the sample farmers was Tk. 32275/ha, of which variable cost was Tk. 20775/ha and fixed cost was Tk. 11500/ha (Table 1). Total returns from the production of groundnut was Tk.55496/ha, while gross margin was Tk. 34721/ha and net return 
was Tk. 23221/ha. The benefit cost ratios over variable costs was 2.67 and over total costs was 1.72 . The study observed that the sample farmers employed 95 man-days/ha of human labour for the production of groundnut. The use of seed was I $07 \mathrm{~kg} / \mathrm{ha}$, urea $50 \mathrm{~kg} / \mathrm{ha}$, TSP $167 \mathrm{~kg} / \mathrm{ha}$, MP $100 \mathrm{~kg} / \mathrm{ha}$, gypsum 45kg/ha and zinc $7 \mathrm{~kg} / \mathrm{ha}$ and they were higher than the recommended doses (Table 3).

Table 1. Per hectare production cost and return of maize, groundnut, mungbean, sweet potato and cabbage cultivation.

\begin{tabular}{l|c|c|c|c|c}
\hline \multirow{2}{*}{\multicolumn{1}{c}{ Parameter }} & \multicolumn{5}{c}{ Taka/ha } \\
\cline { 2 - 6 } & Maize & Groundnut & Mungbean & $\begin{array}{c}\text { Sweet } \\
\text { Potato }\end{array}$ & Cabbage \\
\hline A. Total Variable Costs & $\mathbf{3 3 1 4 1}$ & $\mathbf{2 0 7 7 5}$ & $\mathbf{9 9 9 1}$ & $\mathbf{1 8 0 6 9}$ & $\mathbf{3 7 4 4 9}$ \\
Land preparation & 4359 & 3151 & 2943 & 3476 & 2567 \\
Hired labour & 9000 & 3000 & 2375 & 3420 & 6444 \\
Seed & 3639 & 3639 & 1629 & 4799 & 12526 \\
Cow-dung & 1465 & - & 841 & 1755 & 1465 \\
Urea & 2088 & 319 & 255 & 430 & 1758 \\
TSP & 3200 & 2672 & 1196 & 1776 & 2800 \\
MP & 2565 & 2404 & 199 & 1225 & 2670 \\
Gypsum & 380 & 235 & - & - & 305 \\
Zink & 539 & 518 & - & - & 420 \\
Borax & 231 & - & - & - & 110 \\
Pesticides & 255 & 1095 & 553 & 877 & 1250 \\
Irrigation & 4850 & 3385 & - & - & 4490 \\
Interest on operating capital & 570 & 357 & 153 & 311 & 644 \\
B. Total Fixed Costs & $\mathbf{1 8 2 0 0}$ & $\mathbf{1 1 5 0 0}$ & $\mathbf{1 0 9 9 2}$ & $\mathbf{9 7 5 0}$ & $\mathbf{2 5 5 6 3}$ \\
$\quad$ i.Family labour & 9500 & 6500 & 3325 & 4750 & 17063 \\
$\quad$ ii.Rental value of land & $\mathbf{8 7 0 0}$ & 5000 & 7667 & 5000 & 8500 \\
C. Total Costs ( A+ B) & $\mathbf{5 1 3 4 1}$ & $\mathbf{3 2 2 7 5}$ & $\mathbf{2 0 9 8 3}$ & $\mathbf{2 7 8 1 9}$ & $\mathbf{6 3 0 1 2}$ \\
D. Total Returns & $\mathbf{8 2 6 2 1}$ & $\mathbf{5 5 4 9 6}$ & $\mathbf{3 3 9 4 0}$ & $\mathbf{9 8 8 0 0}$ & $\mathbf{1 1 9 5 5 8}$ \\
$\quad$ i.Value of grains ( yield: & $\mathbf{7 3 6 3 9}$ & & & & \\
$\quad$ 6980/kg/ha) & & & & & \\
$\quad$ ii.Value of by- product & 8982 & & & & \\
E.Gross Margin (D-A) & $\mathbf{4 9 4 8 0}$ & $\mathbf{3 4 7 2 1}$ & $\mathbf{2 3 9 4 9}$ & $\mathbf{8 0 7 3 1}$ & $\mathbf{8 2 1 0 9}$ \\
F. Net Returns ( D- C) & $\mathbf{3 1 2 8 0}$ & $\mathbf{2 3 2 2 1}$ & $\mathbf{1 2 9 5 7}$ & $\mathbf{7 0 9 8 1}$ & $\mathbf{5 6 5 4 6}$ \\
G. Benefit Costs Ratio: & & & & & \\
$\quad$ 1. Over variable cost & 2.49 & 2.67 & 3.40 & 5.46 & 3.19 \\
\hline Souryyyyyy & 1.61 & 1.72 & 1.62 & 3.55 & 1.90 \\
\hline
\end{tabular}

Source: Field survey, 2008

Note: Interest on operating capital has been calculated @ 7\% interest for 3 months period for all crops and vegetables 
Table 2. Per hectare production cost and return of cauliflower, tomato, cucumber and okra cultivation.

\begin{tabular}{|c|c|c|c|c|}
\hline \multirow{2}{*}{ Parameter } & \multicolumn{4}{|c|}{ Taka/ha } \\
\hline & Cauliflower & Tomato & Cucumber & Okra \\
\hline A. Total Variable Costs & 39656 & 55923 & 37580 & 34455 \\
\hline Land preparation & 3096 & 3255 & 1461 & 3525 \\
\hline Hired labour & 5219 & 10665 & 5615 & 7560 \\
\hline Seed & 13576 & 13272 & 8131 & 4800 \\
\hline Cow-dung & 1095 & 3437 & 5663 & 382 \\
\hline Oil cake & - & - & 745 & - \\
\hline Ash & - & - & 27 & - \\
\hline Urea & 1596 & 9900 & 888 & 1494 \\
\hline TSP & 2592 & 5904 & 2862 & 4554 \\
\hline MP & 2895 & - & 2528 & 2574 \\
\hline Gypsum & 685 & - & 450 & - \\
\hline Zink & 1140 & - & - & - \\
\hline Borax & 110 & - & - & 63 \\
\hline DAP & - & - & 1122 & - \\
\hline Pesticides & 1452 & 4058 & 4192 & 5461 \\
\hline Irrigation & 5517 & 4470 & 3250 & 3449 \\
\hline Interest on operating capital & 682 & 962 & 646 & 593 \\
\hline B. Total Fixed Costs & 22272 & 31905 & 27583 & 23320 \\
\hline i.Family labour & 14872 & 15455 & 10098 & 15120 \\
\hline ii.Rental value of land & 7400 & 8600 & 8500 & 8200 \\
\hline iii.Supporting sticks & - & 7850 & 8985 & 57775 \\
\hline C. Total Costs ( A+ B) & 61928 & 87828 & 65163 & \\
\hline D. Total Returns & 134748 & 327054 & 126600 & 152597 \\
\hline \multicolumn{5}{|l|}{$\begin{array}{l}\text { i.Value of grains ( yield: } \\
6980 / \mathrm{kg} / \mathrm{ha} \text { ) }\end{array}$} \\
\hline \multicolumn{5}{|l|}{ ii.Value of by- product } \\
\hline E. Gross Margin (D- A) & 95092 & 271131 & 89020 & 118142 \\
\hline F. Net Returns (D- C) & 72820 & 247076 & 61437 & 94822 \\
\hline \multicolumn{5}{|l|}{ G. Benefit Costs Ratio: } \\
\hline i. Over variable cost & 3.40 & 5.85 & 3.37 & 4.43 \\
\hline ii. Over total cost & 2.17 & 3.72 & 1.94 & 2.64 \\
\hline
\end{tabular}

Source: Field survey, 2008 
It is evident from the Table 1 that the total costs of mungbean cultivation was Tk. 20983/ha, of which variable cost was Tk. 9991/ha and fixed cost was Tk. 10992/ha. The total return was Tk. 33940/ha, whereas gross margins was Tk. 23949/ba and net return was Tk. 12957/ha. Benefit costs ratios for the cultivation of mungbean by the sample farmers were 3.40 and 1.62 over variable costs and total costs, respectively (Table 1). Islam et al. (2008) found BCRs for mungbean 2.53 on variable cost basis and 3.56 on cash cost basis which indicated the reliability of the finding of present study. Levels of major inputs for the cultivation of mungbean were: human labour 60 man-days/ha, seed $30 \mathrm{~kg} / \mathrm{ha}$, urea $36 \mathrm{~kg} / \mathrm{ha}$, TSP $48 \mathrm{~kg} / \mathrm{ha}$, and MP $10 \mathrm{~kg} / \mathrm{ha}$. Most of the inputs used were lower than the recommended doses (Table 3).

Table 3. Level of input use for the cultivation of maize, groundnut, mungbean, sweet potato, and cabbage in study area.

\begin{tabular}{|c|c|c|c|c|c|c|c|c|c|c|}
\hline \multirow{2}{*}{$\begin{array}{c}\text { Name of the } \\
\text { inputs }\end{array}$} & \multicolumn{2}{|c|}{ Maie } & \multicolumn{2}{|c|}{ Groundunt } & \multicolumn{2}{|c|}{ Mungbean } & \multicolumn{2}{|c|}{ Sweet potato } & \multicolumn{2}{|c|}{ Cabbage } \\
\hline & $\begin{array}{c}\text { Dozed } \\
\text { used }\end{array}$ & \begin{tabular}{|c|} 
Rec. \\
dozes
\end{tabular} & $\begin{array}{c}\text { Dozed } \\
\text { used }\end{array}$ & $\begin{array}{l}\text { Rec. } \\
\text { dozes }\end{array}$ & $\begin{array}{l}\text { Dozed } \\
\text { used }\end{array}$ & $\begin{array}{l}\text { Rec. } \\
\text { dozes }\end{array}$ & $\begin{array}{l}\text { Dozed } \\
\text { used }\end{array}$ & $\begin{array}{l}\text { Rec. } \\
\text { dozes }\end{array}$ & $\begin{array}{c}\text { Dozed } \\
\text { used }\end{array}$ & $\begin{array}{l}\text { Rec. } \\
\text { dozes }\end{array}$ \\
\hline $\begin{array}{l}\text { Human (man- } \\
\text { days/ha) }\end{array}$ & 185 & - & 95 & - & 60 & - & 86 & & 235 & - \\
\hline Seed (kg/ha) & 20 & $19-21$ & 107 & $95-100$ & 30 & $25-30$ & 57023 & 56000 & 293 & $300-350$ \\
\hline Urea (kg/ha) & 348 & $500-580$ & 50 & $20-30$ & 36 & $40-50$ & 62 & $140-160$ & 175 & $200-250$ \\
\hline TSP (kg/ha) & 200 & $260-300$ & 167 & $150-170$ & 48 & $80-85$ & 80 & $120-130$ & 178 & $250-300$ \\
\hline MP (kg/ha) & 171 & $185-210$ & 100 & $80-90$ & 10 & $30-35$ & 49 & $160-190$ & 61 & - \\
\hline $\begin{array}{l}\text { Gypsum } \\
\text { (kg/ha) }\end{array}$ & 82 & 210-235 & 45 & $160-180$ & - & - & - & - & 7 & - \\
\hline Zink (kg/ha) & 9 & $12-15$ & 7 & $4-5$ & - & - & - & - & 2 & - \\
\hline $\begin{array}{l}\text { Borax } \\
\text { (kg/ha) }\end{array}$ & 4 & $5-8$ & - & - & - & - & - & - & 0.957 & $5-10$ \\
\hline $\begin{array}{l}\text { Cow-dung } \\
\text { (t/ha) }\end{array}$ & 483 & - & - & - & 1.01 & - & 2.02 & 8.10 & - & - \\
\hline
\end{tabular}

*Number of vines per ha

\section{Vegetables}

Bangladesh produces a wide variety of tropical and sub-tropical vegetables. There is significant potential to develop vegetable production in Bangladesh. Vegetables compare very favourably to other crops in profitability terms and the future performance of the sector will largely determine how successful the country is in diversifying its agricultural production base and achieving higher 
agricultural growth rates (Ateng, 1998; Mahmud et al., 2000). Diversification into vegetable crops and increasing commercialization can support the development of the agricultural sector in several ways. Commercialization is characterized by households moving from subsistence systems into semicommercial and commercial systems (with the main objective of achieving food self-sufficiency), thereby maximizing profits and generating surplus (Pingali and Rosegrant, 1995). Keeping mind this, the farmers produce vegetables and take benefits from high price compared to other crops. In this study, sweat potato, cabbage, cauliflower, tomato, cucumber, and okra considered for investigating profitability point of view.

Present study observed that the total costs of sweet potato cultivation by the sample farmers was Tk. 27819/ha, of which Tk.18069/ha and Tk. 9750/ha were variable costs and fixed costs, respectively (Table 1). The total return received by the farmers was Tk. 98800/ha, while gross margins was Tk. 80731/ha, and net returns was Tk. 70981/ha. The benefit costs ratios were 5.46 and 3.55 over variable costs and total cost respectively. In the cultivation of sweet potato, sample farmers employed 86 man-days/ha of human labour, 57023 no. of vines as seeds, $62 \mathrm{~kg} / \mathrm{ha}$ urea, $80 \mathrm{~kg} / \mathrm{ha}$ TSP, and $49 \mathrm{~kg} / \mathrm{ha}$ MP and they were mostly lower than the recommended doses (Table 3).

The study revealed that the total cost was Tk. 63012/ha for the cultivation of cabbage. Out of a total costs, variable costs was Tk. 37449/ha and fixed cost was Tk. 25563/ha (Table I). It was found from the same table that the total return was Tk. 119558/ha, from which farmers received Tk. 82109/ha as gross margins and Tk. 56546/ha as net returns. The benefit costs ratios over variable cost was 3.19 and over total cost was 1.90. Levels of inputs used by the sample farmers were: human labour 235 man-days/ha, urea 293kg/ha, TSP 175 kg/ha, MP 178 kg/ha, gypsum $61 \mathrm{~kg} / \mathrm{ha}$, zinc $7 \mathrm{~kg} / \mathrm{ha}$, and borax $2 \mathrm{~kg} / \mathrm{ha}$, which were lower but closer to the recommended doses (Table 3).

The total cost of cauliflower cultivation was Tk. 61928/ha, while, variable cost was Tk. 39656/ha and fixed cost was Tk. 22272/ha (Table 2). In the present study, sample farmers received Tk. 134748/ha as total returns, however, gross margin was Tk. 95092/ha and net return was Tk. 72820/ha. The benefit costs ratios were 3.40 and 2.17 over variable costs and total costs, respectively. For the cultivation of cauliflower, human labour requirement was 201 man-days/ha, urea was $266 \mathrm{~kg} / \mathrm{ha}$, TSP $162 \mathrm{~kg} / \mathrm{ha}$, MP $193 \mathrm{~kg} / \mathrm{ha}$, which were more or less equal to the recommended doses (Table 4). 
Table 4. Level of input use for the cultivation of cauliflower, tomato, cucumber, and okra in study area.

\begin{tabular}{|c|c|c|c|c|c|c|c|c|}
\hline \multirow{2}{*}{$\begin{array}{l}\text { Name of the } \\
\text { inputs }\end{array}$} & \multicolumn{2}{|c|}{ Cauliflower } & \multicolumn{2}{|c|}{ Tomato } & \multicolumn{2}{|c|}{ Cucumber } & \multicolumn{2}{|c|}{ Okra } \\
\hline & $\begin{array}{c}\text { Dozed } \\
\text { used }\end{array}$ & $\begin{array}{l}\text { Rec. } \\
\text { dozes }\end{array}$ & $\begin{array}{c}\text { Dozed } \\
\text { used }\end{array}$ & $\begin{array}{l}\text { Rec. } \\
\text { dozes }\end{array}$ & $\begin{array}{c}\text { Dozed } \\
\text { used }\end{array}$ & Rec. dozes & $\begin{array}{c}\text { Dozed } \\
\text { used }\end{array}$ & $\begin{array}{l}\text { Rec. } \\
\text { dozes }\end{array}$ \\
\hline $\begin{array}{l}\text { Human (man- } \\
\text { days/ha) }\end{array}$ & 201 & - & 261 & - & 157 & - & 189 & - \\
\hline Seed (kg/ha) & - & - & $43246 * *$ & - & & & 6 & $4-5$ \\
\hline Urea (kg/ha) & 266 & $250-300$ & 513 & $500-600$ & 148 & $\begin{array}{l}\text { Data not } \\
\text { available }\end{array}$ & 249 & $100-160$ \\
\hline TSP (kg/ha) & 162 & $150-200$ & 396 & $400-500$ & 159 & & 207 & $35-55$ \\
\hline MP (kg/ha) & 193 & $200-250$ & 246 & $200-300$ & 158 & & 143 & $52-80$ \\
\hline $\begin{array}{l}\text { Gypsum } \\
\text { (kg/ha) }\end{array}$ & 137 & - & - & - & 90 & & - & - \\
\hline Zinc (kg/ha) & 19 & - & - & - & & & - & - \\
\hline Borax (kg/ha) & 2 & - & - & - & & & 1 & - \\
\hline $\begin{array}{l}\text { Cow-dung } \\
\text { (t/ha) }\end{array}$ & 2.78 & $15-20$ & - & - & 0.0396 & & 0.955 & - \\
\hline
\end{tabular}

** Seedlings per ha

It was found from the study that the total costs of tomato cultivation was Tk. 87828/ha in which variable cost was Tk. 55923/ha and fixed cost was Tk. 31905/ha. The total returns received by the sample farmers was Tk. 327054/ha while Tk. 271131/ha was received as gross margin and Tk. 247076/ha as net return (Table 2). The benefit costs ratios were found 5.85 and 3.72 over variable costs and total costs, respectively, which are supported by the findings of Karim et al. (2009). They found that BCR for summer tomato was 4.19 on full cost basis and 5.09 on cash cost basis. Levels of inputs used by the sample farmers were: human labour 261 man-days/ha, urea $513 \mathrm{~kg} / \mathrm{ha}$, TSP $396 \mathrm{~kg} / \mathrm{ha}$, and MP $246 \mathrm{~kg} / \mathrm{ha}$, which were roughly equal to the recommended doses (Table 4).

The present study revealed that the total cost of cucumber cultivation by the sample farmers was Tk. 65163/ha, of which variable cost was Tk. 37580/ha, and fixed cost was 27583/ha (Table 2). Total returns was Tk. 126600/ha, however, gross margin was Tk.89020/ha and net return was Tk. 61437/ha with the benefit costs ratios of 3.37 and 1.94 over variable costs and total costs, respectively. In the cultivation of cucumber, human labour employment was 157 man-days/ha, and the use of urea was $148 \mathrm{~kg} / \mathrm{ha}$, TSP $159 \mathrm{~kg} / \mathrm{ha}$, MP $158 \mathrm{~kg} / \mathrm{ha}$, and gypsum $90 \mathrm{~kg} / \mathrm{ha}$ (Table 4). 
Table 5. Constraints to higher production of selected BARI released crop varieties.

\begin{tabular}{l|l|c}
\hline Name of the crops & \multicolumn{1}{c}{ Constraints } & Rank \\
\hline Maize: & $\bullet$ High cost of fertilizers and insecticides & 1 \\
& $\bullet$ High cost of Irrigation & 2 \\
Groundnut: & $\bullet$ High cost of fertilizers and it was not available in time & 1 \\
Munghean: & $\bullet$ High incidence of insects and pests attack & 1 \\
Sweet potato: & $\bullet$ Lack of availability of fertilizers and vines & 1 \\
Cabbage: & $\bullet$ High cost of fertilizers and insecticides & 1 \\
& $\bullet$ High cost of irrigation & 2 \\
Cauliflower: & $\bullet$ High cost seeds & 1 \\
& $\bullet$ High cost of fertilizers and are not available in time & 2 \\
Tomato & $\bullet$ High cost of fertilizers and was not available in time & 1 \\
& $\bullet$ High cost of irrigation & 2 \\
Cucumber: & $\bullet$ High cost of fertilizer and insecticides & 1 \\
Okra: & $\bullet$ Scarcity of good quality seeds & 1 \\
& $\bullet$ High incidence of insects and pests attack & 2 \\
& $\bullet$ High cost of fertilizers and insecticides & 3 \\
\hline
\end{tabular}

It was found from the present study that the total costs of okra cultivation for the sample farmers was Tk. 57775/ha of which Tk. 34455/ha was variable costs and Tk. 23320/ha was fixed costs. Sample farmers received Tk. 152597/ha as total returns, while Tk. 118142/ha was received as gross margins and Tk. 94822/ha as net returns (Table 2). The benefit costs ratios were 4.43 and 2.64 over variable costs and total costs, respectively. Human labour requirement for the cultivation of okra was 189 man-days/ha and application of urea was at the rate of $249 \mathrm{~kg} / \mathrm{ha}$, TSP was $207 \mathrm{~kg} / \mathrm{ha}$, and MP was $143 \mathrm{~kg} / \mathrm{ha}$ (Table 4).

\section{Constraints}

Although all crops and vegetables were observed to be profitable, there are several constraints to its higher production. To identify constraints, farmers were asked a couple of questions. Thereafter, the constraints were edited and summarized to arrive at only few problems. These constraints were arranged in rank value. It is revealed from the Table 5 that high cost of fertilizer and insecticide was first ranked constraints to maize, groundnut, cabbage, and tomato production. High incidence of insects and pests attack, lack of availability of fertilizer and vines, high cost of seeds, scarcity of good quality seeds were the first constraints to mungbean, sweet potato, cauliflower, and okra production. It was followed by high cost of irrigation to maize, cabbage, and tomato cultivation followed by high incidence of insects and pests attack to okra cultivation. 


\section{Conclusions}

The benefit cost ratios of maize, groundnut, mungbean, sweet potato, cabbage, cauliflower, tomato, cucumber, and okra were found 2.49, 2.67, 3.40, 5.46, 3.19, $3.40,5.85$, 3.37, and 4.43 over variable cost and $1.61,1.72,1.62$, 3.55, and 1.90 , 2.17, 3.72, 1.94, 2.64 over total cost, respectively. It is, therefore, evident from the findings of the study that the cultivation of all the selected crops and vegetables are profitable to the farmers. Cultivation of tomato requires highest costs (Tk. 87828/ha) and receives highest net returns (Tk. 247076/ha) as well as highest benefit cost ratios (5.85 over variable costs and 3.72 over total costs) among all the crops and vegetables, tomato cultivation is also a labour intensive crop. It was also found from the study that the total costs of vegetables i.e., cabbage, cauliflower, tomato, cucumber, and okra cultivation were Tk.63012/ha, Tk.61928/ha, Tk.87828/ha, Tk.65l63/ha, and Tk.57775/ha, respectively, as well as received the returns of these vegetables 119558, 134748, 327054, 126600, 152597, respectively, which were higher compared to other crops maize, groundnut, mongbean, and sweet potato. Farmers face problems generally, with the high cost of fertilizers and their availability in time for the cultivation of studied crops.

\section{Policy implications}

- Research institutions, DAE and other related GO/NGO institutions should produce good quality seeds of okra, maize, etc. available to the farmers at reasonable price. Vegetable Section of BARI can take an initiative for supply of BARI cauliflower, tomato, etc. seeds to the farmers through OFRD.

- It may be difficult to cultivate tomato, cucumber, cauliflower for the poor/small farmers as it required higher input costs. Capital may be supplemented to the poor/small farmers for these vegetables cultivation through credit giving agencies with low interest rate and easy terms and condition.

- Policy makers should be given attention to minimize inputs i.e. fertilizers, insecticides cost through input subsidy to cultivate maize, groundnut, cabbage, and tomato and maximize the output price by any means.

- The small, medium, and marginal farmers in the study area can cultivate groundnut, mungbean, and sweet potato easily as it required lower inputs cost which enhances profit. The large farmers may cultivate vegetables i.e. tomato, cauliflower, and okra etc. by utilizing more capital for receiving high gross margin. 


\section{References}

Ateng, B. 1998. Comparative Advantage and Crop Diversflcation, in: Faruqee, R. (ed.), Bangladesh Agriculture in the 21st Century, The University Press Limited, Dhaka.

BBS. 2008. The Statistical Yearbook of Bangladesh, Bangladesh Bureau of Statistics, Planning Division, Ministry of Planning, Government of the People's Republic of Bangladesh, Dhaka, Bangladesh.

Islam, Q.M.S., M.A.M. Miah, Q.M. Alam and S. Hossain, 2009. Profitability level of mungbean cultivation in some selected sites of Bangladesh. Bangladesh J. Agril. Res. 33 (3): 587-595.

Karim, M.R., M. S. Rahman and M. S. Alam. 2009. Profitability of Summer BARI Hybrid Tomato Cultivation in Jessore District of Bangladesh. Journal of Agricultural and Rural Development 7 (1 \& 2), 73-79.

Mahmud, W., S. H. Rahman, and S. Zohir, 20000. Agricultural Diversification: A Strategic Factor for Growth, in: Ahmed, R., Haggblade, S. and T. Chowdhury (eds.), Out of the Shadow of Poverty: Evolving Food Markets and Food Policy in Bangladesh. The John Hopkins University Press: Baltimore and London.

Pingali, P. and M. Rosegrant. 1995. Agricultural commercialization and diversification: Processes and policies. Food Policy 20(3):171-185.

Singh, N. P., A. K. Bhardwaj, Abanish Kumar and K.M. Singh. 2004. Modern Technology on Vegetable Production. International Book Distributing Co. Charman Studio Buildings, $2^{\text {nd }}$ floor, Charbagh, Lucknow 226004, U.P, India.

Swiader, John M., George W. Ware and J.P. Mc Collum. 1992. Producing Vegetable Crops. International Book Distributing Co. Charman Studio Buildings, $2^{\text {nd }}$ Floor, Charbagh, Lucknow 226004, U.P, India. 